\title{
Pengembangan Desain Bahan Ajar Kemampuan Membaca Pemahaman pada Pembelajaran Tematik Terpadu Menggunakan Strategi The Big Question di Kelas V Sekolah Dasar
}

\author{
Ririn Sri Kurnia ${ }^{1}$ \\ Desyandri $^{2}$ \\ Nellitawati $^{3}$
}

\author{
${ }^{123}$ Pendidikan Dasar, Universitas Negeri Padang \\ ririnpermana7@yahoo.com \\ nelitawati@fip.unp.ac.id \\ desyandri@fip.unp.ac.id
}

\begin{abstract}
Abstrak
Membaca adalah identifikasi bentuk-bentuk linguistik. Tujuan penelitian ini adalah Menghasilkan bahan ajar kemampuan pemahaman membaca yang valid, praktis, dan efektif sebagai upaya meningkatkan pembelajaran tematik terpadu dengan menggunakan strategi The Big Question di kelas V Sekolah Dasar. Metode yang digunakan dalam penelitian ini adalah penelitian pengembangan (research and development). Model atau prosedur pengembangan yang digunakan adalah model pengembangan Plomp yang dikembangkan oleh Tjeerd Plomp. Hasil penelitian menunjukan hasil analisis data validasi bahan ajar oleh para ahli dan praktisi pendidikan diperoleh persentase $90,09 \%$. Sedangkan hasil uji efektivitas pada tahap pengembangan, menunjukkan hasil pengamatan terhadap aktivitas peserta didik berada pada kategori sangat baik dengan persentase 93,7\%. Maka dari itu hasil penelitian ini memberi gambaran bahwa bahan ajar yang dikembangkan ini telah valid dan dapat digunakan dalam proses pembelajaran.
\end{abstract}

Kata kunci: Bahan Ajar, Membaca, Tematik

\section{Pendahuluan}

Pelajaran tematik terpadu dalam kurikulum 2013 dilaksanakan untuk meningkatkan serta mengembangkan mutu pendidikan terutama dalam mengimbangi materi pelajaran dalam kurikulum. Pelajaran tematik memberikankesan bermakna pada siswa saat kegiatan belajar mengajar. pelajaran yaitu dengan mengikutsertakan siswa pada aktivitas pelajaran. Pelajaran tematik yaitu kegiatan pelajaran yang memadukan berapa bahan pelajaran ke dalam tema sehingga mampu meningkatkan pengetahuan bagi peserta didik [1]. Perpaduan pelajaran yang tergambar dari kegiatan maupun waktu, kurikulum, serta proses pelajaran. Menurut Prananda, (2020) pelajaran tematik menekankan kepada peserta didik untuk berperan dalam menggali serta menemukan gagasan sesuai dengan prinsip-prinsip secara holistik maupun autentik. dalam penyajian bahan ajar pada pelajaran tematik terpadu pendidik dituntut untuk menyampaikan bahan ajar dari berbagai materi pembelajaran yang ditentukan pada suatu tema yang telah ditetapkan. Berdasarkan penyampaian bahan ajar secara menyeluruh dapat membantu siswa dalam mengetahui bahan ajar. 
Kurikulum 2013 menekankan bahwa pengetahuan tidak dapat dipindahkan annaba gitu saja dari guru kepada siswa. Menurut Riwan dan Bagus (2014) siswa merupakan objek yang mempunyai pengetahuan untuk ikut berperan aktif dalam menemukan serta mengelola wawasan yang didapatnya. Pada kurikulum 2013 mata pembelajaran bahasa Indonesia yaitu mata pembelajaran yang dipelajari. Peranan bahasa Indonesia dijadikan penghila dalam konteks pelajaran yang memiliki arti ganda yakni (1) sebagai pintu masuk untuk memperoleh ilmu pengetahuan dan (2) sebagai instrumen dalam menyampaikan materi pelajaran. Salah satu jenis keterampilan membaca yang diajarkan di SD yakni pemahaman membaca. Pemahaman membaca menurut Mardhatillah dan Trisdania (2018) yakni semacam keterampilan membaca lanjut yang tujuannya untuk mengetahui bacaan. Akan tetapi, dalam penerapannya guru cenderung mengabaikan bagaimana cara keterampilan pemahaman membaca itu. Laily, (2014) juga mengemukakan kemampuan membaca yaitu kecepatan membaca serta pemahaman terhadap isi bacaan secara menyeluruh. Membaca yakni tahapan rumit serta lengkap yang ber maksud tahapan membaca melibatkan berbagai faktor internal maupun eksternal.

\section{Kerangka Teori}

Pelajaran tematik yaitu pelajaran terpadu mengikutsertakan peserta didik dalam kegiatan pelajaran. Menurut Kamus Besar Bahasa Indonesia "Tematik diartikan gagasan suatu cerita (yang dipercakapkan, dipakai sebagai dasar mengarang, menggubah sajak), sedangkan terpadu artinya perpaduan dari beberapa gagasan (disatukan, dilebur menjadi satu)". Berdasarkan gagasan tersebut dapat disimpulkan bahwa "tematik" dan "terpadu" meskipun tampak berbeda tapi maksudnya sama yang ini sama-sama beroperasi dalam penyatuan. Menurut Akrim, (2018) pembelajaran tematik terpadu adalah (Integrated Instruction) pelajaran yang mengharuskan siswa secara pribadi atau kelompok untuk ikut berpartisipasi dalam menemukan serta mencari informasi keilmuan secara holistic. Pelajaran tematik dilakukan dengan memperhatikan prinsip pelajaran terpadu. Kegiatan pelajaran terpadu yang menggabungkan suatu bahan ajar dari beberapa materi pembelajaran yang saling terkait ke dalam satu tema, dilaksanakan dalam satu pertemuan, tidak bertentangan dengan tujuan kurikulum, selalu mempertimbangkan karakteristik peserta didik dalam memberikan pengetahuan yang berwudhu pada siswa.

Penelitian yang dilakukan oleh Mudiono, Gipayana, dan Madyono (2016) mengungkapkan beberapa permasalahan yang terdapat dalam pembelajaran tematik terpadu saat melaksanakan kurikulum 2013 yaitu:, permasalahan pertama, adalah pembelajaran masih berpusat pada guru. Kedua, adalah kurangnya kesempatan mengaktifkan peserta didik, artinya peserta didik kurang diberi kesempatan untuk belajar secara aktif, dan berpikir kritis. Permasalahan ketiga, peserta didik kurang dilatih dan diberikan kesempatan dalam memahami isi bacaan yang terdapat pada materi pembelajaran sehingga peserta didik mengalami kesulitan dalam memahami dan menyerap informasi pada materi pembelajaran. Permasalahan keempat, sebagian guru belum terbiasa dalam keterpaduan satu muatan pembelajaran dengan muatan pembelajaran yang lain, yang terkait pada satu hari pembelajaran, mengakibatkan pemisahan antar muatan pembelajaran masih sangat jelas.

Beberapa peneliti juga menemukan permasalahan pada keterampilan membaca peserta didik di Indonesia, seperti penelitian yang dilakukan oleh Tanggulungan dan Tahir (2015), Desi Sukmawati (2016) mengungkapkan beberapa permasalahan yang 
selalu muncul pada membaca antara lain ialah: (1) rendahnya keterampilan membaca dari segi pemahaman oleh peserta didik, (2) semangat peserta didik terlihat kurang dalam membaca, (3) penerapan membaca belum terlaksana sesuai dengan proses membaca yaitu: prabaca, saat baca dan pascabaca sehingga peserta didik mengalami kesulitan dalam menentukan makna bahan bacaan dan sulit menemukan informasi yang terdapat dalam suatu bacaan, (4) Saat ini minat baca anak Indonesia masih rendah, sehingga berdampak pada kemampuan membaca anak-anak yang masih rendah pula, hasil penelitian tersebut menunjukkan bahwa kemampuan membaca pada anak-anak tingkat Sekolah Dasar (SD) di Indonesia sangat rendah bahkan tertinggal jauh dibandingkan dengan negara-negara lain, (5) Rendahnya kemampuan membaca anak dipengaruhi oleh proses pembelajaran yang dilakukan di sekolah, (6) kurangnya keterampilan guru mengenai strategi atau cara yang efektif dalam mengajarkan membaca.

Membaca yaitu suatu cara untuk mengetahui ilmu-ilmu beberapa cabang ilmu dalam bentuk tulisan yang dapat membentuk tulisan yang diwujudkan untuk menghasilkan tanda-tanda konvensional dalam bentuk linguistik yang sama dalam penyajian yang berbeda. Pandangan tentang defenisi membaca juga dikemukakan oleh Irdawati dan Yunidar (2015) membaca yaitu suatu aktivitas yang diperlukan untuk mendapatkan pengetahuan yang dapat dijadikan bekal dalam menghadapi kehidupan dikarenakan membaca dapat memperoleh gagasan atau informasi yang baru sehingga dapat menambah pengetahuan serta wawasan pembaca. Manfaat membaca dijelaskan oleh Basuki, (2011) dengan membaca mampu menyembuhkan pengetahuan serta kemampuan berpikir untuk memperluas pengetahuan pembaca sehingga dapat dijadikan sebagai alat komunikasi masyarakat berbudaya yang berperan penting dalam kehidupan sosial. membaca yaitu setting kegiatan berinteraksi dalam mengetahui lambang bahasa dengan cara pendekatan supaya mengetahui maksud suatu gagasan tertulis yang mengikutsertakan siswa dalam suatu kegiatan, visual, psikolinguistik dan metakognitif.

Membaca berkaitan dengan kegiatan berpikir dalam mengetahui isi gagasan yang dibaca. maka dari itu membaca tidak hanya sekedar melihat beberapa huruf yang membentuk kata, kelompok kata, kalimat, paragraf, serta wacana akan tetapi lebih dari itu membaca yaitu aktivitas mengetahui tulisan serta informasi yang tergambar dalam suatu gagasan. Salah satu aktivitas jenis membaca adalah pemahaman membaca. Menurut Zare dan Othman (2013) mengemukakan membaca pemahaman yaitu suatu penambahan pengetahuan mengenai apa yang dibaca. Membaca pemahaman juga dijelaskan oleh Puspita, (2018) membaca dapat diartikan sebagai suatu proses untuk memahami yang tersirat dalam yang tersurat, yakni memahami makna yang terkandung untuk mengungkapkan bahwa membaca adalah aktivitas kognitif yang kompleks berfungsi untuk mendapatkan informasi. pemahaman membaca adalah membaca untuk mengetahui isi bacaan untuk mendapatkan gagasan atau ide dalam suatu gagasan yang dibaca.

\section{Metode}

Model perkembangan yakni suatu tahapan yang dilakukan secara urut dalam melakukan perencanaan dalam mengembangkan pelajaran yang digambarkan dalam bentuk bagan (diagram) maupun naratif. Model atau prosedur perkembangan pelajaran yang diterapkan yakni model pengembangan Plomp dikemukakan oleh Tjeerd Plomp. 
Model Plomp mempunyai beberapa tahapan yakni pendahuluan (preliminary research), yaitu tahapan persiapan yang terdiri dari analisis kebutuhan, analisis peserta didik, analisis kurikulum, dan analisis konsep. Fase pengembangan atau pembuatan prototype (development or prototypingphase), tahapan perencanaan serta pengembangan perangkat pelajaran yang secara bertahap yang memerlukan evaluasi formatif dalam menumbuhkan serta meningkatkan prototype yang dikembangkan. Sedangkan fase penilaian (assessment phase) gambar prototype akhir maupun produk yang cocok dengan yang diinginkan serta mengajukan rekomendasi dalam pengembangan produk [14].

\section{Hasil}

Hasil penelitian perkembangan kemampuan pemahaman membaca yang di jadikan sebagai usaha dalam mengembangkan pelajaran tematik terpadu yang memerlukan pendekatan The Big Question di kelas V SD dapat disajikan dalam bab ini. Format dan penyusunan materi pelajaran dibentuk berdasarkan struktur materi pelajaran berdasarkan Depdiknas yang meliputi : (1) Cover, (2) Kata pengantar, (3) Daftar isi, (4) Petunjuk penggunaan, (5) kompetensi inti, (6) judul subtema dan pemetaan kompetensi dasar, (7) Peta Konsep, (8) Jaringan tema atau kompetensi yang akan dicapai, (9) Paparan atau Penyajian Materi, (10) Refleksi dan (11) Daftar pustaka. Materi pembelajaran terdiri dari materi pelajaran yang digunakan pendidik serta penyampaian materi pelajaran kepada siswa yang bertujuan utuk memudahkan guru melaksanakan pembelajaran dan penilaian. Hasil materi pelajaran dapat dilihat sebagai berikut :

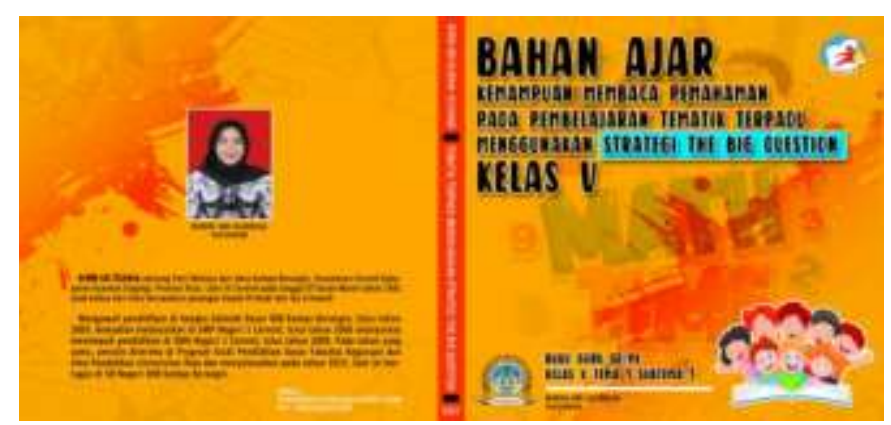

Gambar 1. Cover (Kuliti Bahan Ajar)

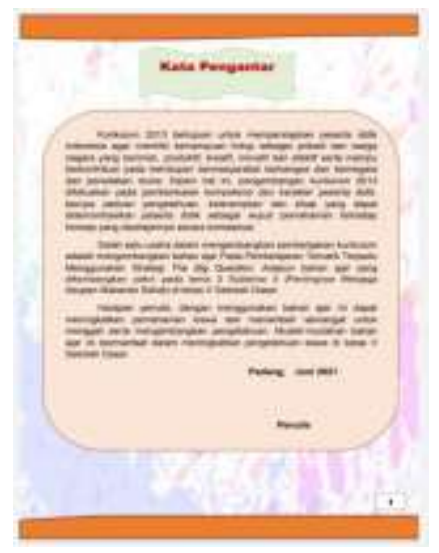

Gambar 2. Desain Kata Pengantar Buku Guru dan Buku Peserta didik 

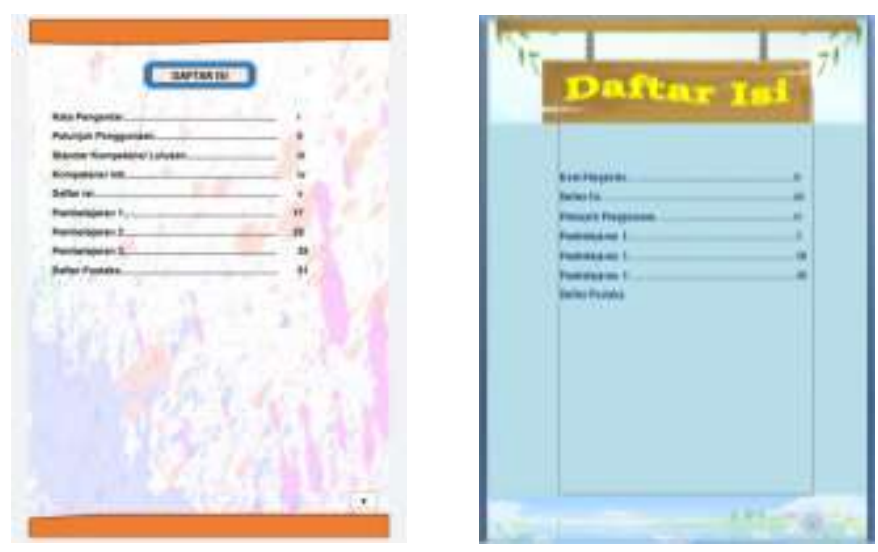

Gambar 3. Desain Daftar Isi Bahan Ajar Buku Siswa (kiri) dan Buku Guru (kanan)
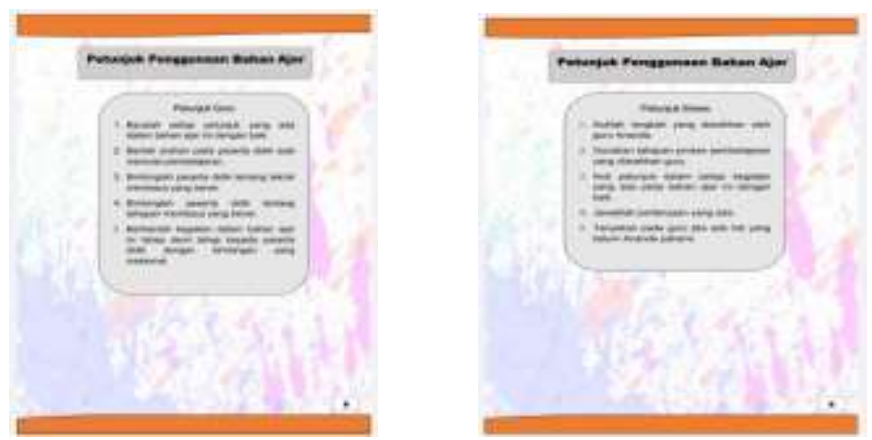

Gambar 4. Desain Petunjuk Buku Guru (kiri) dan Buku Peserta didik (kanan)

\section{Validasi Bahan Ajar}

Hasil perencanaan yang dilanjutkan dalam proses validasi. terdapat dua proses yang dilaksanakan saat dan validasi materi pelajaran yakni self evaluation serta validasi oleh expert reviews. Berikut akan diuraikan hasil validasi dan revisi prototype yang telah dirancang.Tahap validasi meliputi validasi materi pelajaran yang digunakan. Pengujian validitas yaitu materi pelajaran yang digunakan yang meliputi sefl evaluation, serta validasi oleh expert reviews dan praktisi pendidikan lalu melakukan perbaikan. Pengujian praktikalitas yakni melakukan field test yang telah diterapkan saat kegiatan pelajaran di kelas.

Validasi RPP divalidasi oleh validator ahli dan validator praktisi. Validator RPP dilaksanakan dengan melihat beberapa kategori yakni identitas, perumusan tujuan pembelajaran, pemilihan materi pembelajaran, metode dan kerincian langkah-langkah pelajaran, pemilihan sumber belajar, serta evaluasi. Data hasil validasi RPP pemahaman membaca yang dijadikan sebagai usaha dalam mengembangkan pelajaran tematik terpadu yang memerlukan pendekatan The Big Question oleh validator ahli secara menyeluruh tergambar dalam Diagram dibawah ini.

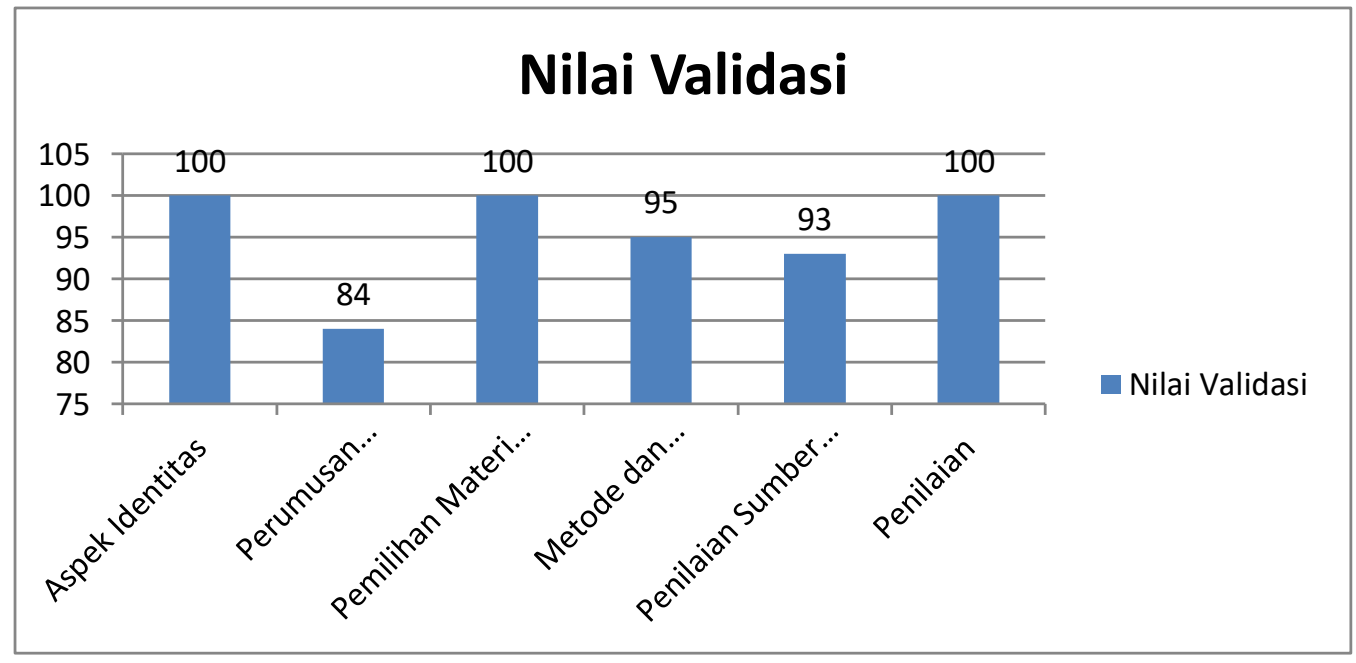




\section{Gambar 5. Nilai Validasi RPP}

Hasil validasi RPP seperti pada diagram diatas yang dijabarkan diketahui ratarata hasil validasi setiap indikator berkisar dari 83,3 sampai 100 dengan kategori sangat valid dan hasil validasi secara keseluruhan yakni 95,33 \% yang di kategori sangat valid. Kategori sangat valid artinya RPP telah divalidasi oleh validator ahli sudah dapat digunakan. Disamping itu peneliti juga meminta validator praktisi untuk menilai RPP yang telah peneliti rancang. Peneliti menentukan praktisi berdasarkan pengalaman mengajar dan akademis yang dimiliki oleh praktisi. Untuk memvalidasi rancangan RPP dalam penelitian ini peneliti meminta praktisi dalam memberikan penilaian serta saran perbaikan dari RPP yang telah ditentukan.

Validasi materi pelajaran dilaksanakan dalam beberapa yakni kesesuaian dengan isi, aspek kebahasaan, dan aspek kegrafikaan. Secara umum validasi materi pelajaran dalam kategori kelayakan isi yakni nilai rata-rata dalam pernyataan berpisah antara 75\% s/d 100\% yang termasuk pada kelompok valid. Rata-rata validitas yang mencakup seluruh aspek kesesuaian dengan isi yakni 91,87\% yang dikelompokkan ke dalam kelompok yang valid. Artinya, secara menyeluruh isi materi pelajaran sesuai dengan aspek kelayakan isi misalnya yang telah ditentukan. Jadi, bisa ditarik kesimpulannya yakni materi pelajaran keterampilan pemahaman membaca yang dijadikan sebagai usaha dalam mengembangkan pelajaran tematik terpadu yang memerlukan pendekatan The Big Question telah baik dan valid digunakan dalam proses pembelajaran. Penilaian materi pelajaran selanjutnya dari aspek kebahasaan.

Pada kategori penilaian memiliki rentang nilai 75\% s/d 100\% terdapat pada kategori valid dan sangat valid. Validitas kebahasaan secara menyeluruh yakni 89\% yang digolongkan sangat valid. Jadi, bisa diungkapkan bahasa yang yang digunakan dalam materi pelajaran sesuai dengan kaidah bahasa Indonesia yang baik, benar, mudah dipahami, komunikatif, jelas, dan singkat.

Sedangkan kategori penilaian kegrafikaan mempunyai rentang nilai 75\% s/d $100 \%$ yang berada pada kategori valid dan sangat valid. Validitas kategori kegrafikaan secara menyeluruh yakni $88,75 \%$ dengan kelompok sangat valid. Ini bisa dikatakan aspek kegrafikaan materi pelajaran sudah sesuai yakni valid. Jadi, dapat disimpulkan bahwa materi pelajaran pemahaman membaca yang dijadikan sebagai usaha dalam mengembangkan pelajaran tematik terpadu yang yang memerlukan pendekatan The Big Question yang discussion memiliki bentuk yang menarik, memiliki warna yang bervariasi, dan sesuai dengan materi pembelajaran tematik terpadu. Validasi bahan ajar secara keseluruhan berdasarkan aspek isi, kebahasaan, dan kegrafikaan bisa dilihat pada Diagram dibawah ini.

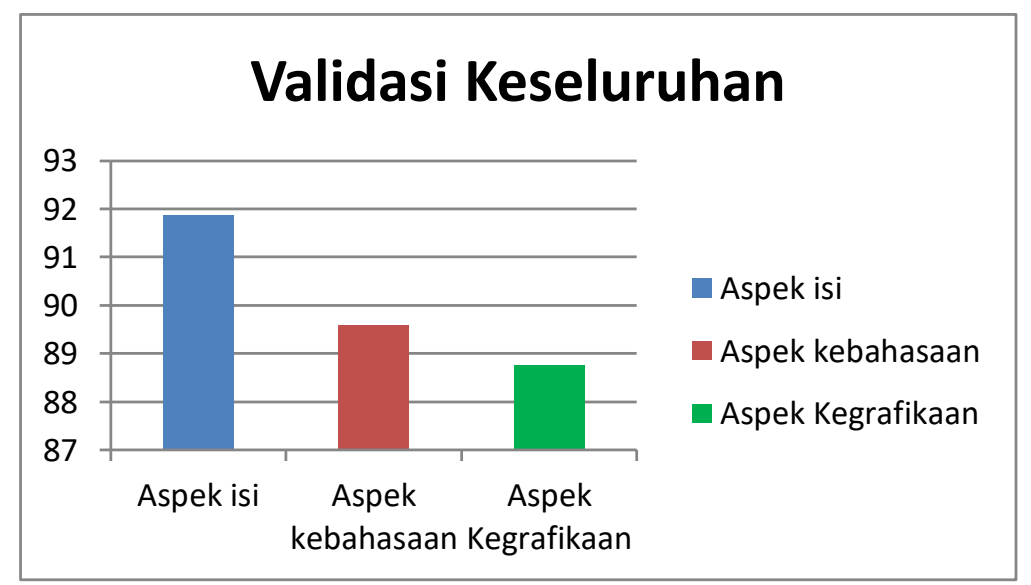


Rata-rata keseluruhan validasi diperoleh persentase 90,08\% dengan kriteria sangat valid. Validasi pada aspek isi diperoleh persentase 98,87\% dengan kategori sangat valid. Kategori kebahasaan diperoleh persentase $89,58 \%$ dengan kategori sangat valid. Aspek kegrafikaan didapatkan persentase 88,75\% yang dikelompokkan sangat valid. Jadi dapat disimpulkan hasil validasi yang dilakukan oleh validator ahli sangat valid serta bisa dilanjutkan dalam uji praktikalitas.

\section{Hasil Angket Respon Peserta Didik Terhadap Prototype}

Evaluasi angket respon peserta didik diberikan untuk megetahui pendapat siswa mengenai tingkat kemudahan materi pelajaran. Angket praktikalitas diberikan kepada siswa kelas VA SDN 008 Kompe Berangin dengan jumlah 15 orang. persentase kepraktisan lembar respon peserta didik berkisar dari 90 sampai 98,3 dengan kategori sangat praktis dan persentase kepraktisan lembar respon siswa secara keseluruhan yakni 94,5\% yang digolongkan mudah. Berdasarkan data tersebut, artinya materi pelajaran pemahaman membaca dijadikan sebagai usaha dalam mengembangkan pelajaran tematik terpadu yang mengguakan pendekatan The Big Question dapat dikategorikan sangat praktis, karena peserta didik merasa termotivasi untuk membaca, yang didalam bahan ajar terdapat beragam gambar dan warna- warna yang bervariasi, dan merasa terbantu Pada pelaksanaan pelajaran tematik terpadu serta siswa lebih mudah memahami materi. Siswa mendapatkan pengetahuan baru pada materi pelajaran dikarenakan materinya berbeda dengan materi yang telah digunakan.

\section{Aktivitas Peserta didik}

Kegiatan siswa dalam proses pelajaran yang memerlukan materi pelajaran pemahaman membaca yang dijadikan usaha dalam mengembangkan pelajaran tematik terpadu yang memerlukan pendekatan The Big Question yang diteliti oleh peneliti. Kegiatan yang dijadikan sebagai bahan dalam penelitian yakni (1) Visual Activities yaitu peserta didik memperhatikan bahan ajar, (2) Listening Activities yaitu peserta didik memperhatikan dan mendengarkan penjelasan guru, (3) Oral Activities yaitu peserta didik mengajukan pertanyaan atau memberikan pendapat, (4) Writing Activities yaitu peserta didik mengerjakan latihan pada bahan ajar dan (5) Motor Activities yaitu peserta didik melakukan langkah-langkah pada bahan ajar,. Hasil penelitian dalam kategori tergambar dalam Bagan 1.

Tabel 1. Hasil Pengamatan Aktivitas Peserta didik

\begin{tabular}{|c|c|c|c|c|c|c|c|c|}
\hline & & $\begin{array}{c}\text { Visual } \\
\text { Activities }\end{array}$ & $\begin{array}{l}\text { Listening } \\
\text { Activities }\end{array}$ & $\begin{array}{c}\text { Oral } \\
\text { Activities }\end{array}$ & $\begin{array}{c}\text { Writing } \\
\text { Activities }\end{array}$ & $\begin{array}{c}\text { Motor } \\
\text { Activities } \\
\end{array}$ & & \\
\hline 1 & Pertemuan I & $92 \%$ & $97 \%$ & $92 \%$ & $89 \%$ & $86 \%$ & 91,2 & $\begin{array}{l}\text { Sangat } \\
\text { Baik }\end{array}$ \\
\hline 2 & Pertemuan II & $92 \%$ & $94 \%$ & $89 \%$ & $92 \%$ & $97 \%$ & 93 & $\begin{array}{l}\text { Sangat } \\
\text { Baik }\end{array}$ \\
\hline 3 & Pertemuan III & $97 \%$ & $100 \%$ & $94 \%$ & $97 \%$ & $100 \%$ & 97 & $\begin{array}{c}\text { Sangat } \\
\text { Baik }\end{array}$ \\
\hline & & & Rata-rata & & & & 93,7 & $\begin{array}{c}\text { Sangat } \\
\text { Baik }\end{array}$ \\
\hline
\end{tabular}

Dari paparan di atas, memberikan gambaran bahwa materi pelajaran pemahaman membaca yang dijadikan sebagai usaha dalam mengembangkan pelajaran tematik terpadu dengan memerlukan pendekatan The Big Question yang dikembangkan dapat 
membantu dalam meningkatkan aktivitas peserta didik. Selain itu, pendidik dimudahkan dengan adanya materi pelajaran yang dikembangkan. Bahan ajar memberikan sugesti positif bagi peserta didik untuk belajar, yang diindikasikan pada peningkatan kegiatan siswa pada ada kegiatan belajar mengajar. Maka dari itu, tergambar dari kegiatan siswa materi pelajaran pemahaman membaca yang dijadikan sebagai usaha dalam mengembangkan pelajaran tematik terpadu yang memerlukan pendekatan The Big Question yang dikembangkan sudah efektif diterapkan dalam pembelajaran.

\section{Penilaian Hasil Belajar Peserta Didik}

Penilaian dalam kategori sikap dilaksanakan pada kegiatan pelajaran yang memerlukan rubik penilaian sama seperti saat praktikalitas. Jurnal penilaian sikap menilai tentang sikap yang muncul dan menonjol dalam pembelajaran yang berlangsung. Adapun kategori yang dinilai yakni sikap aspek spiritual serta aspek sikap sosial. Pada penilaian sikap peserta didik di kelas VB SDN 008 Kompe Berangin setelah 3 pembelajaran, guru mencatat tingkah laku peserta didik pada lembar jurnal penilaian sikap. Hasil penilaian sikap peserta didik dapat berperilaku syukur, percaya diri, disiplin dan santun dalam pembelajaran.

Penilaian pada kategori keterampilan dilaksanakan pada kegiatan pelajaran dengan saat praktikalitas. Analisis belajar yang telah dicapai dengan persentase sebesar 93\% kategori sangat baik, maka terlihat bahwa pembelajaran dengan menggunakan materi pelajaran pemahaman membaca yang dijadikan sebagai usaha dalam mengembangkan pelajaran tematik terpadu yang memerlukan pendekatan The Big Question pada tema 3 Makanan Sehat subtema 3 Pentingya Menjaga Asupan Makanan Sehat dapat membantu peserta didik meningkatkan aspek keterampilannya.

Penilaian aspek pengetahuan dilakukan dilakukan untuk mengukur tingkat ketuntasan belajar peserta didik. Setelah melakukan proses pembelajaran diberikan soal untuk mengukur kemampuan peserta didik. Analisis terhadap perkembangan belajar yang terlihat pada materi pemahaman membaca yang dijadikan sebagai usaha dalam mengembangkan pelajaran tematik terpadu dengan menerapkan pendekatan The Big Question pada tema 3 Makanan Sehat subtema 3 Pentingya Menjaga Asupan Makanan Sehat, dapat membantu peserta didik saat mengamati pelajaran sehingga didapatkan hasil sebesar $90 \%$ kategori sangat baik. Apabila evaluasi yang didapatkan siswa berada diatas KKM sekolah yakni 75 secara menyeluruh pelajaran yang memerlukan materi pelajaran pemahaman membaca yang dijadikan sebagai usaha dalam mengembangkan pelajaran tematik terpadu yang memerlukan pendekatan The Big Question dikatakan tuntas.

\section{Simpulan}

Temuan ini tergambar dari hasil penelitian materi pelajaran pemahaman membaca yang dijadikan sebagai usaha dalam mengembangkan pelajaran tematik terpadu yang menerapkan pendekatan The Big Question yang telah dilaksanakan. Praktikalitas materi pelajaran pemahaman membaca yang dijadikan sebagai usaha dalam mengembangkan pelajaran tematik terpadu yang yang memerlukan pendekatan The Big Question secara keseluruhan yang dikategorikan mudah. Ini tergambar dari hasil penelitian keterlaksanaan RPP pada pendidikan yang menyampaikan materi pelajaran, respon pendidik serta peserta didik, dan pengamatan yang dilaksanakan. Pelaksanaan bahan ajar oleh pendidik dapat membantu serta mempermudah dalam kegiatan pelajaran tematik terpadu dengan memahami isi materi di kelas. Sedangkan Efektivitas 
pengembangan materi pelajaran pemahaman membaca yang dijadikan untuk mengembangkan pelajaran tematik terpadu yang memerlukan pendekatan The Big Question di kelas V SD yang didapatkan dari pengamatan perkembangan yang dinyatakan terlaksana dalam menumbuhkan kemampuan membaca peserta didik.

\section{Ucapan Terima Kasih}

\section{Daftar Pustaka}

H. Karli, "Penerapan Pembelajaran Tematik Sd Di Indonesia," EduHumaniora J. Pendidik. Dasar, vol. 2, no. 2, pp. 321-325, 2015.

A. . Y. Prananda, Gingga. Wardana, "Pengembngan Media Video Pembelajaran Tema 6 Subtema 2 Untuk Siswa Kelas SD Negeri 17 Pasar Masurai 1," J. Dharma PGSD, vol. 1, no. 1, pp. 38-45, 2020.

N. L. G. Riwan Putri Bintari, I. N. Sudiana, and I. Bagus Putrayasa, "Pembelajaran Bahasa Indonesia Berdasarkan Pendekatan Saintifik ( Problem Based Learning ) Sesuai Kurikulum 2013 Di Kelas Vii Smp Negeri 2 Amlapura," e- J. Progr. Pascasarj. Univ. Pendidik. Ganesha, vol. 3, no. 1, pp. 1-10, 2014.

Mardhatillah and E. Trisdania, "Pengembangan Media Pembelajaran Berbasis Macromedia Flash Untuk Meningkatkan Kemampuan," Bina Gogik J. Ilm. Pendidik. Guru Sekol. Dasar, vol. 5, no. 1, pp. 91-102, 2018.

I. F. Laily, "Hubungan Kemampuan Membaca Pemahaman Dengan Kemampuan Memahami Soal Cerita Matematika Sekolah Dasar," Eduma Math. Educ. Learn. Teach., vol. 3, no. 1, 2014, doi: 10.24235/eduma.v3i1.8.

Akrim, Nurzanah, and N. Ginting, "Pengembangan Program Pembelajaran Tematik Terpadu Bagi Guru-Guru Muhammadiyah di Kota Medan," J. Prodikmas Has. Pengabdi. Masyrakat, vol. 2, no. 2, pp. 103-111, 2018, [Online]. Available: http://jurnal.umsu.ac.id/index.php/prodikmas/article/view/2462/pdf_19.

A. Mudiono, M. Gipayana, and S. Madyono, "Developing of Integrated Thematic Learning Model through Scientific Approaching with Discovery Learning Technique in Elementary School," Int. Acad. J. Soc. Sci., vol. 3, no. 10, pp. 19-27, 2016.

V. L. Tanggulungan and M. Tahir, "Peningkatan Kemampuan Membaca Permulaan Melalui Media Kartu Kata Siswa Kelas I SD Inpres 1 Kamarora," J. Kreat. Tadulako Online, vol. 5, no. 7, pp. 227-239, 2015.

I. C. Desi Sukmawati, "Efektivitas Model Concerntrated Languange Encounter (CLE) Dalam Peningkatan Keterampilan Membaca Siswa Sekolah Dasar," JPSD, vol. 2, no. 1, pp. 26-38, 2016.

D. M. Irdawati, Yunidar, "Meningkatkan Kemampuan Membaca Permulaan Dengan Menggunakan Media Gambar Kelas 1 di Min Buol," J. Kreat. Tadulako Online, vol. 5, no. 4, pp. 1-14, 2015.

I. A. Basuki, "Kemampuan Membaca Pemahaman Siswa Kelas IV SD Berdasarkan Tes Internasional dan Tes Lokal," Bhs. Dan Seni, vol. 39 nomor 2, pp. 202-212, 2011.

P. Zare and M. Othman, "The Relationship between Reading Comprehension and Reading Strategy Use among Malaysian ESL Learners," Int. J. Humanit. Soc. Sci., vol. 3, no. 13, pp. 187-193, 2013.

R. D. Puspita and 'R., "a Meningkatkan Kemampuan Membaca Pemahaman Berbantuan Pembelajaran Tematik Terpadu Bernuansa Model Interactive-Compensatory.," Pendas J. Ilm. Pendidik. Dasar, vol. 2, no. 2, p. 198, 2018, doi: 10.23969/jp.v2i2.557.

T. \& N. N. Plomp, "Educational Design Research/Part A: An introduction. Netherlands:," in SLO Netherlands Institute for curriculum Development, 2013, p. 2013. 